\title{
Antibacterial Efficacy of Moringa oleifera Leaf against Medically Important Clinical Pathogens
}

\author{
P. Manikandan ${ }^{1}$, A. Gnanasekaran ${ }^{1}$, P. Julikarthika ${ }^{1}$ and D. Arvind Prasanth ${ }^{2} *$ \\ ${ }^{1}$ Department of Microbiology, Kandaswami Kandar's College, P. Velur, India \\ ${ }^{2}$ Department of Microbiology, School of Biosciences, Periyar University, Salem, India
}

*Corresponding author

\section{Keywords}

Moringa oleifera

Leaf,

Antibacterial activity,

Phytochemical analysis.

\section{Article Info}

Accepted:

09 March 2016

Available Online:

10 April 2016

\section{A B S T R A C T}

Moringa oleifera Leaf (Moringaceae) is a very useful tree in tropical countries. The antimicrobial activity of Acetone, Chloroform, Methanol and Petroleum ether extract of Moringa oleifera leaf against ten microorganisms Escherichia coli, Staphylococcus aureus, Klebsiella pneumoniae, Pseudomonas aeruginosa, Streptococcus pyogens, Bacillus Sp, Proteus Sp Salmonella Sp Streptococcus mutants, Shigella $s p$ along with positive controls. It was observed that methanol extract of Moringa oleifera showed highest antimicrobial activity against while petroleum their extract exhibited greater antimicrobial activity against all the tested bacteria. So this plant extracts having good healing properties without side effects when compared with synthetic antibiotics.

\section{Introduction}

Medicinal plants have been used for centuries as remedies for human diseases because they contain components of therapeutic value. The plants have always been vital for mankind irrespective of the era and area all over the globe since the beginning of life. (Bukar, 2009).

Medicinal plants contain numerous biologically active compounds, many of which have been shown to have antimicrobial properties. Plant-derived medicines have been part of traditional healthcare in most parts of the world for thousands of years and there is increasing interest in plants as sources of agents to fight microbial diseases (Thilza et al., 2010).

Moringa oleifera is a well-documented world renowned plant for its extraordinary nutritional and medicinal properties. It is a natural antihelmintic, antibiotic, detoxifier, outstanding immune builder and is used in many countries to treat malnutrition and malaria. It is also used in water purification and therefore helps in reducing the incidence of water borne diseases (Marcu, 2004). 
Phytochemicals are chemical compounds that are naturally found in plant. They are responsible for the colour and organoleptic properties of the plant. It is also referred to as those chemicals that may have biological significance but are not established as essential nutrients in plant. (Ugwu Okechukwu et al., 2013). They are used Phytochemicals are dietary supplements, but the potential health benefits of Phytochemicals are derived from consumption of the whole plant (Riad et al., 2014).

\section{Materials and Methods}

\section{Collection and Processing of Plant Materials}

The fresh leaves of Moring oleifera were collected from Pokkam Palayam, Namakkal District, and Tamilnadu, India.

\section{Preparation of Extracts}

The dried plant material was crushed in to fine particles (powder) using a mixer. About 25 grams of each plant powdered material was separately extracted with $100 \mathrm{ml}$ of solvents (Acetone, Chloroform, Methanol and Petroleum ether) respectively. All the solvents were kept at room temperature, for 7days to allow the extraction of the compounds from plants. Each mixture was stirred every 24 hours using sterile glass rod. The greenish extracts obtained were passed through the whattman filter paper No: 1 and the respective solvents were evaporated with the help of heating mantel. The sticky black substances obtained was stored in the refrigerator and dissolved in Dimethyl Sulphoxide(DMSO) prior to use.

\section{Phytochemical Screening of the Plant Extract}

The extracts were subjected to phytochemical screening for identification of its active chemical constituents. Phytochemical analysis of extract for qualitative detection of Alkaloids, Flavonoids, Saponins, Tannins, Terpenoids, Phyto steroids, Carbohydrates was performed by the extracts.

\section{Antibacterial Screening of Plant Extract}

The antibacterial activities of the plant were tested against the selected bacterial strain by following the method of the sterilized Mueller Hinton agar medium was poured in to each sterile petri plate and allowed to solidify. Using sterile cotton swabs the test bacterial cultures were evenly spread over the media. The sterile discs were individually loaded with different concentrations of organic solvent extracts (Acetone, Chloroform, Methanol, and Petroleum Ether) of the plant. Then the discs were placed on the top layer of the Petri dishes pertaining to the test cultures. All the plates were incubated at $37^{\circ} \mathrm{C}$ for 24 hours. After the incubation period the results were observed and measured the diameter to demarcate inhibition zone around each disc/ organism.

\section{Results and Discussion}

\section{Screening of Antibacterial Activity}

Four different organic solvents (Acetone, Chloroform, Methanol, Petroleum Ether) at various concentrations $(25 \mu 1,50 \mu 1,75 \mu 1$, $100 \mu \mathrm{l})$ of Moringa oleifera was evaluated for its antimicrobial activity. Both Gram positive and Gram negative organisms were screened in this study. The results were tabulated in Table 1.

The results of the present study shoes that most of the organic solvent extracts of Moringa oleifera Leaf showed significant activity against the tested bacterial strains. 
The disc containing lest amount of solvent extract, $25 \mu 1 /$ disc had similar antibacterial activity of the tested microorganisms, Escherichia coli (8 mm), Staphylococcus aureus (11 mm), Klebsiella sp (11-17 mm), Pseudomonas aeruginosa (9-15 $\mathrm{mm})$, Streptococcus pyogens (11-15 mm), Proteus $\mathrm{sp}(15 \mathrm{~mm})$, Salmonella sp (8-12mm), Shigella sp (8-12mm), Streptococcus mutants (11 mm), Bacillussp (10-20 mm).

In case of $50 \mu \mathrm{l}$ shows a fair antibacterial activity against the bacterial tested, Escherichia coli (9 mm), Staphylococcus aureus (11-14 mm), Klebsiella sp (9-17 $\mathrm{mm})$, Pseudomonas aeruginosa (9-10 mm), Streptococcus pyogens (7-18 mm), Proteus sp (10-17mm), Salmonella sp (817mm), Shigella sp (8-17mm),Streptococcus mutants (12mm), Bacillus sp (12-21mm).

The disc containing $75 \mu \mathrm{l} /$ disc extracts showed a better result, Escherichia coli (9$13 \mathrm{~mm})$, Staphylococcus aureus (10-17 $\mathrm{mm})$ Klebsiella sp (11-15 $\mathrm{mm})$, Pseudomonas aeruginosa (11-13 $\mathrm{mm})$, Streptococcus pyogens $(820 \mathrm{~mm})$, Proteus sp (11-21mm), Salmonella sp (9-17mm), Shigella sp (917mm), Streptococcus mutants (9-12mm), Bacillus sp (12-24mm).

The higher concentration of the extract 100 $\mu 1 /$ disc shows a good activity the tested organisms, Escherichia coli(10-18 mm), Staphylococcus aureus (12-20 $\mathrm{mm})$, Klebsiella sp (10-17 mm),Pseudomonas aeruginosa (12-16 $\mathrm{mm})$, Streptococcus pyogens (8-28mm), Proteus sp (11-31mm), Salmonella sp (10-20mm), Shigella sp (13$27 \mathrm{~mm})$, Streptococcus mutants (10-15mm), Bacillus sp (12-28mm). (Table.1)

\section{Phytochemical Analysis of Moringa oleifera}

The presence of Phytochemicals in the plant under study was evaluated. It is reported to predominantly contain a wide range of chemicals in different extracts. The acetone extract contains the following constituents, Terpenoids, Tannins, Saponins, Flavanoids and Alkaloids. The chloroform extract contains Carbohydrates, Terpenoids, Tannins, Saponins, Flavanoids and Alkaloids. The methanol extract contains Terpenoids and Phyto Steroids. The petroleum ether extract contains Alkaloids, Flavanoids, Saponins, Terpenoids, Phyto Steroids and Tannins (Table.2).

In the present study, the plant Moringa oleifera was evaluated for its antibacterial properties against both gram positive and gram negative organisms. Various organic solvent extracts with different concentrations were analyzed for the current investigation. From the screening results it was observed that most of the extracts were found to inhibit the growth of the organisms. The results indicated that some of the secondary metabolites present in the plant part may be responsible for this activity.

Plant based antimicrobial represents the vast untapped source for medicine. Plant based antimicrobials have enormous therapeutic potential as they can solve the purpose without any side effects, that are often associated with synthetic antimicrobials, continued further research and exploration of plant derived antimicrobials needed today. 
Table.1 Antibacterial activity of Moringa oleifera

\begin{tabular}{|c|c|c|c|c|c|c|}
\hline \multirow[t]{2}{*}{ SI.NO } & \multirow[t]{2}{*}{$\begin{array}{l}\text { NAME OF THE } \\
\text { ORGANISMS }\end{array}$} & \multirow[t]{2}{*}{ SOLVENT } & \multicolumn{4}{|c|}{$\begin{array}{c}\text { Diameter Zone of inhibition } \\
(\mathrm{mm}) \text { at different concentration } \\
\text { of the extracts. }\end{array}$} \\
\hline & & & $25 \mu \mathrm{l}$ & $50 \mu \mathrm{l}$ & $75 \mu \mathrm{l}$ & $100 \mu \mathrm{l}$ \\
\hline \multirow{4}{*}{1.} & \multirow{4}{*}{ Escherichia coli } & Acetone & - & 9 & 10 & 11 \\
\hline & & Chloroform & - & 9 & 9 & 10 \\
\hline & & Methanol & - & - & - & - \\
\hline & & Petroleum ether & 8 & 9 & 13 & 18 \\
\hline \multirow{4}{*}{2.} & \multirow{4}{*}{ Staphylococcus aureus } & Acetone & 11 & 14 & 17 & 20 \\
\hline & & Chloroform & - & - & 10 & 12 \\
\hline & & Methanol & - & 11 & 13 & 16 \\
\hline & & Petroleum ether & - & 11 & 15 & 19 \\
\hline \multirow{4}{*}{3.} & \multirow{4}{*}{ Klebsiella $s p$} & Acetone & - & - & 12 & 9 \\
\hline & & Chloroform & 9 & 10 & 10 & 10 \\
\hline & & Methanol & - & - & 13 & - \\
\hline & & Petroleum ether & 7 & 9 & 12 & 9 \\
\hline \multirow{4}{*}{$4 .}$. & \multirow{4}{*}{ Pseudomonas aeruginosa } & Acetone & 10 & - & 12 & 10 \\
\hline & & Chloroform & 13 & - & 12 & - \\
\hline & & Methanol & - & - & - & - \\
\hline & & Petroleum ether & 10 & 11 & 11 & 9 \\
\hline \multirow{4}{*}{5.} & \multirow{4}{*}{ Streptococcus pyogens } & Acetone & 11 & 12 & 17 & 20 \\
\hline & & Chloroform & - & 7 & 8 & 8 \\
\hline & & Methanol & 14 & 16 & 20 & 20 \\
\hline & & Petroleum ether & 15 & 18 & 20 & 30 \\
\hline \multirow{4}{*}{6.} & \multirow{4}{*}{ Bacillus sp } & Acetone & 20 & 21 & 24 & 28 \\
\hline & & Chloroform & 12 & 15 & 18 & 20 \\
\hline & & Methanol & 13 & 15 & 17 & 18 \\
\hline & & Petroleum ether & 10 & 10 & 12 & 12 \\
\hline \multirow{4}{*}{7.} & \multirow{4}{*}{ Proteus sp } & Acetone & - & 10 & 10 & 13 \\
\hline & & Chloroform & - & 10 & 10 & 11 \\
\hline & & Methanol & - & 10 & 11 & 13 \\
\hline & & Petroleum ether & 15 & 17 & 21 & 31 \\
\hline \multirow{4}{*}{8.} & \multirow{4}{*}{ Salmonella $s p$} & Acetone & 12 & 17 & 17 & 20 \\
\hline & & Chloroform & 8 & 8 & 9 & 10 \\
\hline & & Methanol & 10 & 11 & 12 & 16 \\
\hline & & Petroleum ether & - & 10 & 10 & 12 \\
\hline \multirow{4}{*}{9.} & \multirow{4}{*}{ Streptococcus mutants } & Acetone & 11 & 12 & 12 & 14 \\
\hline & & Chloroform & 11 & 12 & 13 & 15 \\
\hline & & Methanol & - & - & 11 & 12 \\
\hline & & Petroleum ether & - & - & 9 & 10 \\
\hline \multirow{4}{*}{10.} & \multirow{4}{*}{ Shigella $s p$} & Acetone & 12 & 17 & 17 & 20 \\
\hline & & Chloroform & 8 & 8 & 9 & 10 \\
\hline & & Methanol & 10 & 11 & 12 & 16 \\
\hline & & Petroleum ether & - & 10 & 10 & 12 \\
\hline
\end{tabular}


Table.2 Phytochemical Screening of Moringa oleifera

\begin{tabular}{|l|l|l|l|l|c|}
\hline SI.NO & Constituents & Acetone & Chloroform & Methanol & $\begin{array}{c}\text { Petroleum } \\
\text { Ether }\end{array}$ \\
\hline 1 & Alkaloids & + & + & - & + \\
\hline 2 & Flavonoids & + & + & - & + \\
\hline 3 & Saponins & + & + & - & + \\
\hline 4 & Tannins & + & + & - & + \\
\hline 5 & Terpenoids & + & + & + & + \\
\hline 6 & Phyto Steroids & - & - & + & + \\
\hline 7 & Carbohydrates & - & + & - & + \\
\hline
\end{tabular}

Medicinal plants are important source for the development of potential new chemotherapeutic drugs and the in vitro antibacterial test from basis. Many of the studies were useful in identifying the active principle responsible for such potentials and to develop clinically important therapeutic drugs for mankind.

The present study focused on the medicinal plant Moringa oleifera for its antibacterial activity, Phytochemical analysis.

In conclusion, plants used in traditional are assumed to be safe due to the long-term use by traditional healers. Herbal medicinal preparations and their proprietary products are being used more and more widely throughout the world for treating various ailments. Hence evaluating and ensuring their quality becomes increasingly urgent.
Many medicinal plants have been found effective in the cure of bacterial diseases. Due to increasing antibiotic resistance in microorganisms and side effects of synthetic medicinal plants are now gaining popularity in the treatment of bacterial infections. Medicinal plants are considered as clinically effective and safer alternatives to the synthetic antibiotics.

\section{References}

Abalaka, M.E., Daniyan, S.Y., Oyeleke, S.B., Adeyemo, S.O., et al. 2012. The Antibacterial Evaluation of Moringa oleifera Leaf Extracts on Selected Bacterial Pathogens. J. Microbiol. Res., 2(2): 1-4.

Ashok, V., Gomashe, Pranita, A., Gulhane, Megha, P., Junghare, Neeta, A., Dhakate. 2014. Antimicrobial Activity 
of Indian Medicinal Plants: Moringa oleifera and Saraca indica. Int. J. Curr. Microbiol. Appl. Sci., 3(6): 161-169.

Bukar, A., Mukhtar, D., Hassan, A.S. 2009. Photochemical Screening and Antibacterial activity of leaf extract of Senna siamea (Lam) on Pseudomonas aeuroginosaet alBayero. J. Pure and Appl. Sci., 2(1): 139-142.

Bukar, A., Uba, A., Oyeyi, T.I., et al. 2010. Antimicrobial Profile of Moringa oleifera lams. Extracts against some food - borne microorganisms. Bayero J. Pure and Appl. Sci., 3(1): 43-48.

Devendra, B.N., Srinivas, N., Prasad, V.S.S.L., Talluri, Swarnalatha, P., et al. 2011. Antimicrobial activity of Moringa oleifera lam., leaf extract, against selected bacterial and fungal strains. Int. J. Pharma and Bio Sci., 2(3).

Eman, N., Ali, et al. 2014. Moringa oleifera Leaves Possible uses as environmentally Friendly Material: A REVIEW. Int. J. Chem. Environ. Biol. Sci., 2(2): 141-145.

Gruvinder, Pal Singh, Sandeed Kumar, Sharma, et al. 2012. Antimicrobial evaluation of leaf extracts of Moringa oleifera Lam. Int. Res. J. Pharm., 3(4): 212-214.

Gustavo Hitzschky Fernandes Vieira, Jozeanne Alves Mourao, Angela Maria Angelo, Renata Albuquerque COSTA, Regine Helena Silva dos Fernandes Vieira. 2010. Antibacterial effect (in vitro) of Moringa oleifera and Annona muricata against Gram positive and Gram negative bacteria. Rev. Inst. Med. Trop. Sao Paulo, Vol. 52(3): 129-132.

Josephine, N., Kasolo, Gabriel, S., Bimenya, Lonzy Ojok, Joseph Ochieng, Jasper, W., Ogwal-Okeng, et al. 2010. Phytochemicals and uses of Moringa oleifera leaves in Ugandan rural communities. J. Med. Pl. Res., 4(9): 753-757.

Kalpana, S., Moorthi, S., Sushila kumara, et al. 2013. Antimicrobial activity of different extracts of leaf of Moringa oleifera (Lam) against gram positive and gram negative bacteria. Int. $J$. Curr. Microbiol. Appl. Sci., 2(12): 514518.

Kaniz Fatima Urmi, Nurul Huda, M.D., Masum, Abu Hasanat, M.D., Zulfiker, M.D., Kamal Hossain, Kaiser Hamid, et al. 2012. Comparative Antimicrobial activity and brine shrimp lethality bioassay of different parts of the plant Moringa oleifera lam. J. Appl. Pharma. Sci., 2(12): 085-088.

Khawaja Tahir Mahmood, Tahira Mugal, Ikram Ul Haq, et al. 2010. Moringa oleifera: a natural gift-A review. $J$. Pharma. Sci. Res., 2(11): 775-781.

Kodia, M., Trébissou Jonhson Noel, D., Crezoit Yapo, A., Eyangoh, S., Asse, H. et al. 2014. Effects of Moringa oleifera, A Plant Extract Coded OBAYOKOU on Ulcers Caused by Mycobacterium ulcerans in Children under 15 Years in Côte d'Ivoire. Int. J. Pharma. Sci. Drug Res., 6(2): 137-139.

Makanjuola, O.O., Dada, E.O., Ekundayo, F.O. et al. 2013. Antibacterial activities of Moringa oleifera (lam) on Coliforms isolated from some surface waters in akure, nigeria. FUTA J. Res. Sci., (1): 63-71.

Memnune Sengul, Hilal Yildiz, Neva Gungor, Bulent Cetin, Zeynep Eser, EzaiErcisli, et al. 2009. Total Phenolic content, Antioxidant and Antimicrobial activities of some medicinal plants. Pak. J. Pharm. Sci., 22(1): 102-106.

Mohammed Abu Sayeed, Mohammad Shahadat Hossain, Mohammad Ehsanul Hoque Chowdhury, Mohsinul Haque, et al. 2012. In vitro Antimicrobial activity of Methanolic extract of 
Moringa oleifera Lam. Fruits. $J$. Pharmacognosy and Phyto Chem., 1(4): 94-98.

Mona, M., Abdalla, et al. 2013. The potential of Moringa oleifera extract as a bio stimulant in enhancing the growth, biochemical and hormonal contents in rocket (Eruca vesicaria subsp. sativa) plants. Int. J. Pl. Physiol. Biochem., 5(3): 42-49.

Mudasser Zaffer, Showkat Ahmad,Rajendra Sharma, Surabhi Mahajan, Ankur Gupta, Rajneesh Agnihotri. et al. 2012. Antifungal activity and preliminary Phytochemical analysis of bark extracts of Moringa oleifera Lam. Int. J. Biosci., 2(12): 26-30.

Namrata Prasad, Dipika Nandi, Surabhi Arora, Amit. et al. 2014. Pandey In Vitro Evaluation of Antibacterial Properties of Moringa oleifera, Dalbergia sissoo and Alstonia scholar's. J. Biol. Agri. Healthcare, (15): 54-62.

Patil, S.D., Jane Rasika. 2013. Antimicrobial activity of Moringa oleifera and its synergism with Cleome viscosa. Int. J. Life Sci., Vol. 1(3): 182-189.

Philip, C.N., Alikwe, Elijah, I., Ohimain, Douye, V., Zige, Tariwari, N.C., Angaye. et al. 2013. Antibacterial activity of ethanol extract of the defatted seed and seed coat of Moringa oleifera. IOSR J. Pharm. Biol. Sci., 8(1): 38-41.

Renu Solanki. 2010. Some medicinal plants with Antimicrobial activity. Pharmacie Globale (IJCP), Vol 1(4): 70-78.

Riad, S.R., EI-Mohamedy, Aboelfetoh, M., Abdalla, Safia, M., Adam, et al. 2014. Preliminary studies on response of Moringa oleifera plants to infection with some soil borne plant pathogenic fungi. Int. J. Curr. Microbiol. Appl. Sci., 3(12): 389-397.
Rockwood, J.L., Anderson, B.G., Casamatta, D.A., et al. 2013. Potential uses of Moringa oleifera and an examination of antibiotic efficacy conferred by Moringa oleifera seed and leaf extracts using crude extraction techniques available to underserved indigenous populations. Int. J. Phytothearpy Res., 3(2): 61-71.

Theophilus, U., Onyekaba, Omojate Godstime Chinedu, Anowi Chinedu Fred. et al. 2013. Phytochemical Screening and Investigations of Antibacterial activities of various fractions of the ethanol leaves extract of Moringa oleifera lam (Moringaceae). J. Pharma. Chem. Biol. Sci., 3(3): 962-973.

Thilza, I.B., Sanni, S., Zakari Adamusah, F.S., Sanni, Muhammed Talle, Musa Bamaiyi. 2010. Joseph invitro Antimicrobial activity of water extract of Moringa oleifera leaf stalk on bacteria normally implicated in eye diseases. Vol. 2(6): 80-82.

Tona, G.O., Ogunbosoye, D.O., Bakare, B.A., et al. 2014. Growth performance and nutrient digestibility of West African Dwarf goats fed graded levels of Moringa oleifera leaf meal. Int. J. Curr. Microbiol. Appl. Sci., 3(8): 99106.

Ugwu Okechukwu, P.C., Nwodo Okwesili, F.C., Joshua Parker, E., Bawa Abubakar, Ossai Emmanuel, C., Odo Christian, E., et al. 2013. Phytochemical and acute toxicity studies of Moringa oleifera ethanol leaf extract. Int. J. Life Sci. Biotechnol. Pharma Res., 2(2): 65-71.

Vinoth, B., Manivasaga perumal, R., Balamurugan, S., et al. 2012. Phytochemical analysis and Antibacterial activity of Moringa oleifera lam. Int. J. Res. Biol. Sci., 2(3): 98-102. 
Yogesh kumar Vaghasiya, Sumitra Chada, V., et al. 2007. Screening of Methanol and Acetone extracts of fourteen
Indian Medicinal plants for antibacterial activity. Turuky J. Biol., 234-248.

\section{How to cite this article:}

Manikandan, P., A. Gnanasekaran, P. Julikarthika and Arvind Prasanth, D. 2016.

Antibacterial Efficacy of Moringa oleifera Leaf against Medically Important Clinical Pathogens. Int.J.Curr.Microbiol.App.Sci. 5(4): 109-116.

doi: http://dx.doi.org/10.20546/ijcmas.2016.504.015 